\title{
KARAKTERISASI EMISI PAHs HASIL PEMBAKARAN DUPA DALAM RUANG EKSPERIMEN
}

\section{CHARACTERIZATION OF PAHs EMISSION FROM INCENSE BURNING IN EXPERIMENTAL CHAMBER}

\author{
Retno Puji Lestari ${ }^{1,3}$, Samroeng Chantchaemsai ${ }^{2}$ dan Panida Navasumrit ${ }^{2,3}$
}

(Diterima tanggal 09-06-2016; Disetujui tanggal 18-02-2016)

\begin{abstract}
ABSTRAK
Pembakaran dupa yang merupakan bagian dari ritual agama dan budaya mayoritas komunitas Oriental, diketahui berpotensi menyebabkan efek berbahaya akibat emisi yang menghasilkan berbagai jenis polutan. Telah dilakukan identifikasi senyawa Polycylic Aromatic Hydrocarbons (PAHs) yang berasal dari emisi hasil pembakaran beberapa tipe dupa dalam sebuah ruang eksperimen. Studi ini dilakukan di Chulabhorn Research Institute, Thailand dengan tujuan untuk mengetahui tingkat emisi PAHs yang terikat dalam partikulat pada sampel-sampel dupa dari tiga negara (Indonesia, Thailand, dan Vietnam) yang dipilih secara acak. Dari hasil analisis PAHs menggunakan High Performance Liquid Chromatography dengan Fluorescence Detector (HPLC-FLD) diketahui bahwa komponen dominan dalam sampel dupa Indonesia dan Thailand adalah fluorenthane (Flu) dengan konsentrasi masing-masing $8.2 \pm 1.0$ dan $3.5 \pm 0.5 \mu \mathrm{g} / \mathrm{m}^{3}$, sementara sampel Vietnam didominasi oleh komponen chrysene (CHR) $\left(34.5 \pm 10.6 \mu \mathrm{g} / \mathrm{m}^{3}\right)$. Sampel dupa Vietnam mengemisikan total PAHs $\sim 5$ kali lebih tinggi dari dupa Indonesia dan $\sim 8$ kali lebih tinggi dari dupa Thailand. Seluruh sampel mengemisikan Benzo[a]pyrene (BaP) dalam level serupa, meskipun konsentrasi dalam dupa Vietnam masih $\sim 1.3$ kali lebih tinggi dari dupa Indonesia dan $\sim 1.8$ kali dari dupa Thailand. Sementara untuk nilai BaP ekivalen, dupa Vietnam $\sim 3.7$ kali dan $\sim 7$ kali lebih tinggi dari sampel Indonesia dan Thailand.
\end{abstract}

Kata kunci: polusi udara, HPLC-FLD, total PAHs, BaP, BaP ekivalen

\begin{abstract}
Incense burning, which is the common practice for the majority of Oriental society, had been acknowledged to potentially cause adverse effects due to the production of various air pollutants. Polycylic aromatic hydrocarbons (PAHs) emissions bound to particulate matter from the combustion of several type incense sticks were characterized in the experimental chamber. This study is conducted in Chulabhorn Research Institute, Thailand which is aimed to quantify the emmission level of particle-bound PAHs from selected random incense sticks of three countries (Indonesia, Thailand, and Vietnam). High Performance Liquid Chromatography with Fluorescence Detector (HPLCFLD) for analysis of PAHs found that the major compound in Indonesian and Thai incenses was fluorenthane Flu (8.2 2.1 .0 and $3.5 \pm 0.5 \mu \mathrm{g} / \mathrm{m}^{3}$, respectively), while it was CHR $\left(34.5 \pm 10.6 \mu \mathrm{g} / \mathrm{m}^{3}\right)$ in Vietnamese incenses. Vietnamese incense emitted the highest total PAHs, with $\sim 5$ and $\sim 8$ times higher than that of Indonesian and Thai incense, respectively. All incenses emitted BaP in similar level, although Vietnamese incense was still $\sim 1.3$ times higher than Indonesian incense and $\sim 1.8$ times higher than Thai incense. As for BaP equivalent, Vietnamese incense was $\sim 3.7$ and $\sim 7$ times higher than that of Indonesian and Thai incense, respectively.
\end{abstract}

Key words: air pollution, HPLC-FLD, total PAHs, BaP, BaP ekivalen

\section{PENDAHULUAN}

Salah satu aktivitas yang dikategorikan sebagai sumber pencemar udara dalam ruangan adalah proses pembakaran dupa yang umumnya menjadi salah satu ritual komunitas Oriental. Pembakaran dupa berpotensi menimbulkan resiko terhadap kesehatan manusia dan penurunan kualitas lingkungan. Proses

\footnotetext{
P3KLL-KLHK, Kawasan PUSPIPTEK, Serpong, 021-7560981, 15310, emc_acdep@yahoo.com

${ }^{2}$ Chulabhorn Research Institute, Laksi, Bangkok, 10210

${ }^{3}$ Environmental Toxicology Program, Chulabhorn Graduate Institute, Laksi, Bangkok, 10210
} 
pencemaran udara dalam ruangan umumnya terlokalisasi dalam satu area dan periodik (1). Emisi yang dihasilkan bersifat singkat, sporadik, dan tidak dapat diprediksi (2).

Penelitian mengenai dampak pembakaran dupa telah banyak dilakukan di negara-negara pengguna dupa terutama di Taiwan. Secara umum dilakukan pengujian kualitas udara ambien di tempat-tempat yang menjadikan proses pembakaran dupa sebagai ritual keagamaan seperti kuil maupun rumah (3-5). Selain itu dilakukan pula pengujian berbagai polutan dalam ruang eksperimen (6), dan studi epidemiologi mengenai efek dupa terhadap kesehatan manusia $(3,7,8)$. Beberapa studi di Cina mempelajari berbagai jenis bahan baku dupa dan efek emisinya (9-11), sedangkan sebuah studi di Timur Tengah meneliti tentang efek asap pembakaran dupa terhadap hewan percobaan (12). Seiring tersebarnya populasi komunitas Oriental di berbagai negara yang mengaplikasikan budaya tradisi dan religi, penggunaan dupa juga banyak ditemukan di negara-negara Asia Tenggara seperti Thailand, Vietnam, Indonesia, atau Singapura. Kendati demikian, studi tentang efek pemakaian dupa yang sudah dilakukan di negaranegara tersebut sangat terbatas, sementara itu belum ditemukan publikasi khusus mengenai penelitian tentang dupa di Indonesia. Hal ini menjadi ide penelitian untuk mengetahui kandungan PAHs dari beberapa merek dupa yang lazim digunakan masyarakat. Pemilihan sampel untuk keperluan penelitian dilakukan secara acak yaitu sampel-sampel dupa yang berasal dari Indonesia, Vietnam, dan Thailand.

Proses pembakaran dupa yang tidak sempurna berlangsung secara perlahan dan kontinyu, menghasilkan asap yang mengandung berbagai gas-gas berbahaya misalnya senyawa volatile organic compounds (VOCs) (13), aldehida aromatik $(10,14)$, polycyclic aromatic hydrocarbon compounds (PAHs) (15-17) juga senyawa-senyawa logam yang terkandung dalam partikulat dan abu $(4,9,15,18)$.

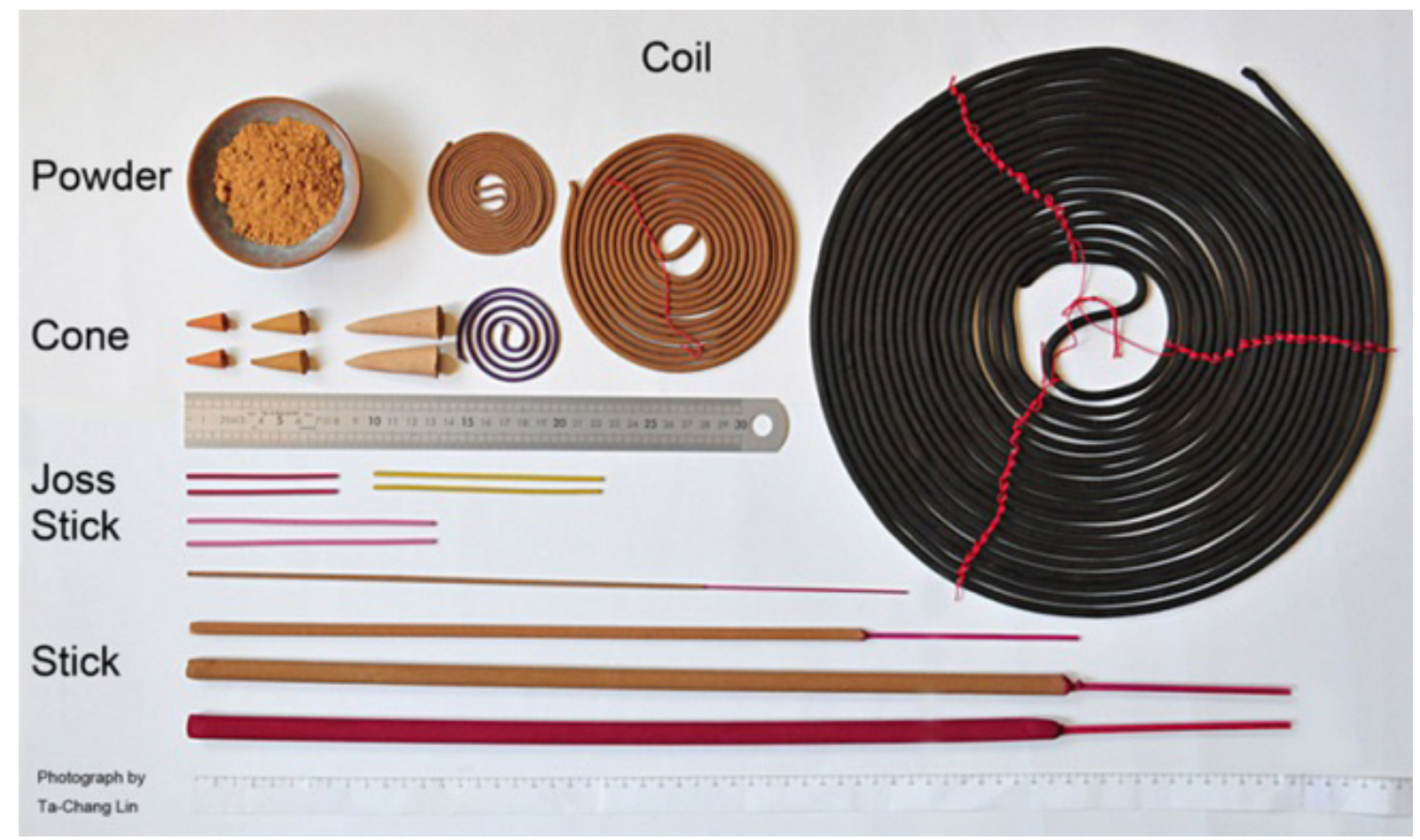

Gambar 1. Variasi jenis dupa (foto : TC Lin) (19) 
Dupa dibuat dalam berbagai desain seperti bubuk, kerucut, stik, atau joss stik. Dupa bergagang bambu atau kayu (stik) merupakan bentuk yang lazim digunakan. Awalnya dupa dibuat dari campuran berbagai bahan alam seperti kayu, bunga, daun, atau getah pohon. Namun seiring perkembangan jaman dan ketersediaan bahan baku, senyawa-senyawa kimia yang digunakan sebagai bahan pengisi, bahan pengikat, maupun wewangian mulai ditambahkan dalam proses pembuatan untuk meminimalisasi harga produk. Hal tersebut berpotensi menambah efek yang merugikan bagi kesehatan manusia.

PAHs adalah senyawa-senyawa yang terdiri dari tiga atau lebih cincin benzene yang dihasilkan melalui pembakaran tak sempurna dari komponen organik (20). PAHs mudah larut dalam berbagai pelarut organik, sukar larut dalam air, dapat terfotooksidasi oleh cahaya dan terdegradasi menjadi senyawa yang lebih sederhana (21). Senyawa dengan $\mathrm{BM}$ rendah cenderung berada dalam fase gas, sementara senyawa dengan BM yang lebih tinggi (lebih dari 4 cincin benzene) memiliki tendensi untuk terikat dalam partikulat (20). Dalam analisis PAHs menggunakan HPLCFLD, dapat ditentukan berbagai jenis senyawa PAHs, termasuk BaP. BaP adalah salah satu komponen kunci senyawa PAHs yang paling banyak diteliti dan dikategorikan oleh IARC sebagai probable human carcinogen (2A). $\mathrm{BaP}$ biasanya digunakan sebagai penanda (marker) dari aktivitas karsinogen senyawa PAHs karena mempunyai karakteristik yang telah diketahui dengan baik.Konsentrasi tiap senyawa individu PAHs dihitung sebagai $\mathrm{BaP}$ equivalent menggunakan toxicity equivalency factors (TEF) untuk setiap komponen agar bisa dibandingkan dengan BaP. Nilai TEF (tanpa satuan) untuk tiap individual PAHs diadopsi dari Nisbet dan LaGoy (1992) dan dirangkum dalam EPA. Nilai TEF tersebut merupakan estimasi terhadap toksisitas relatif tiap individu $\mathrm{PAH}$ dibandingkan dengan $\mathrm{BaP}$ (20).

\section{METODOLOGI}

Pengujian dilakukan di Laboratory of Environmental Toxicology, $2^{\text {nd }}$ Floor, Biomedical Science Building, Chulabhorn Research Institute, Bangkok - Thailand. Sampel-sampel dupa Indonesia, Vietnam, dan Thailand dipilih secara acak dari pasar lokal yang berada di wilayah Tangerang, Hanoi, dan Bangkok. Terdapat masing-masing lima sampel dupa dari tiap-tiap lokasi, Kode dan keterangan pengamatan fisik sampel dapat dilihat pada Tabel 2. Setelah melakukan pengamatan fisik yang meliputi panjang, berat, warna, dan aroma, sebesar $10 \mathrm{~cm}$ dari bagian dupa dipotong dan ditimbang ulang. Pengujian emisi hasil pembakaran dupa dilakukan dalam skala laboratorium pada kotak eksperimen terbuat dari akrilik dengan dimensi 46(L) x 35(W) x 39(D) $\mathrm{cm}$ yang dilengkapi dengan exhaust fan. Bagian dupa yang telah dipotong dibakar dalam ruang eksperimen sampai habis, lalu dibiarkan selama 2 menit kemudian dilakukan pengambilan sampel PAHs menggunakan filter gelas fiber (Macherry-Nagel $ø 37 \mathrm{~mm}$ ) dan pompa SKC air check sampler model 224PCXR8. Laju alir pengambilan sampel adalah $2 \mathrm{~L} /$ menit dengan total volume sebanyak 4 L. Filter yang mengandung fase partikulat PAHs tersebut kemudian diekstrak dengan Dichloromethane (DCM), dipekatkan dengan 


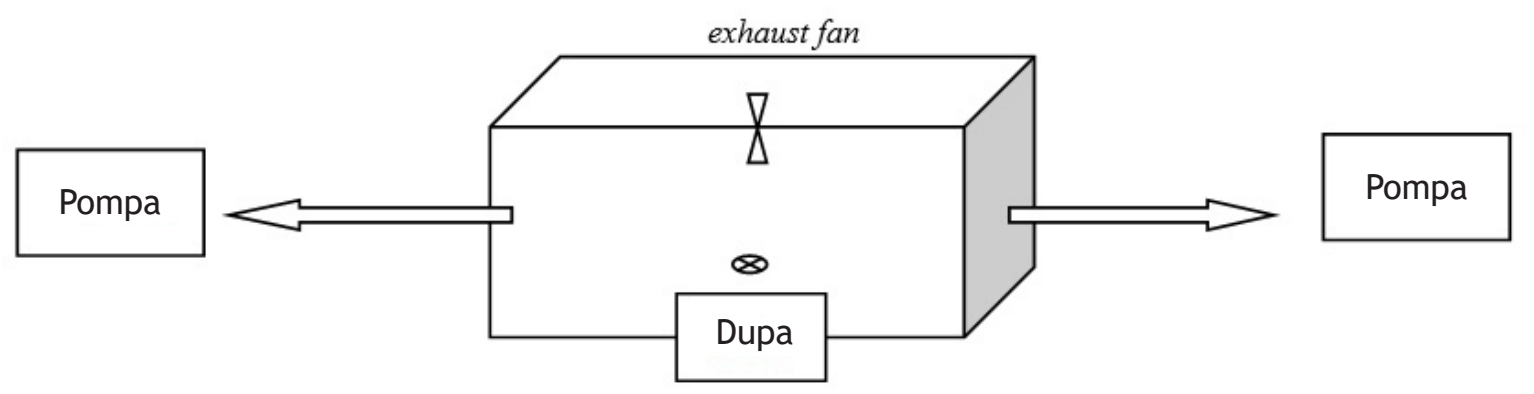

Gambar 2. Skema Pengambilan Contoh Uji

aliran $\mathrm{N}_{2}$, dan dilarutkan dengan asetonitril. Kandungan 10 PAHs seperti Anthracene (Ant), Flu, Pyrene (Pyr), Benzo[a]anthracene (BaA), CHR, Benzo[a]fluorenthane (BaF), Benzo[b] fluorenthane $(\mathrm{BbF})$, Benzo[k]fluorenthane (BkF), BaP, Dibenz[a,h]-acridine (DBahA), dan Benzo[g,h,i]perylene (BghiP) ditetapkan menggunakan peralatan HPLC-FLD dengan kolom LiChrospher PAH (250x3mm) pada $18^{\circ} \mathrm{C}$ menggunakan $60-100 \%$ gradien asetonitril dan laju alir $0.56 \mathrm{~mL} / \mathrm{menit}$.

\section{Sifat Fisik Dupa}

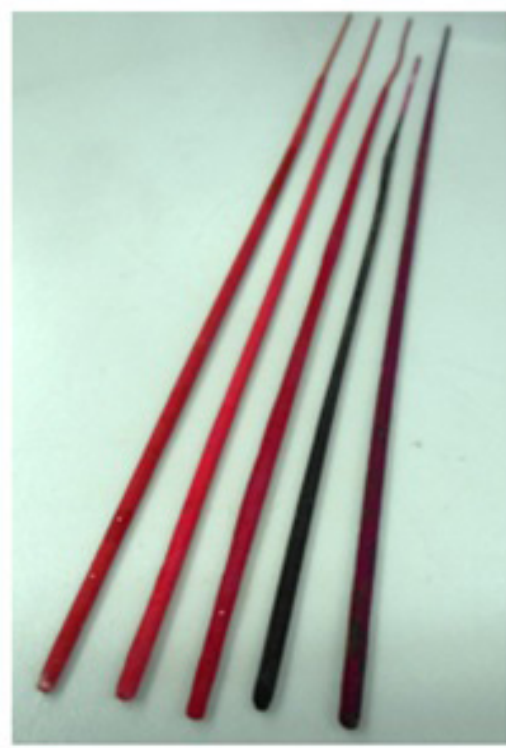

(1) Kode A-E

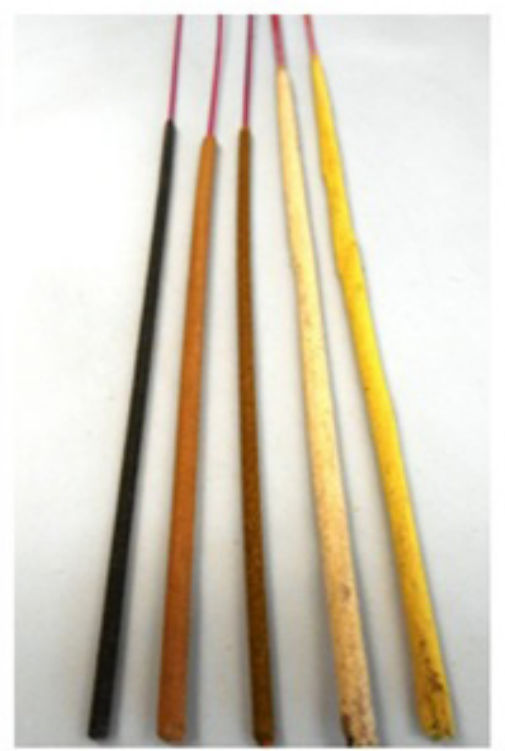

(2) Kode F-J

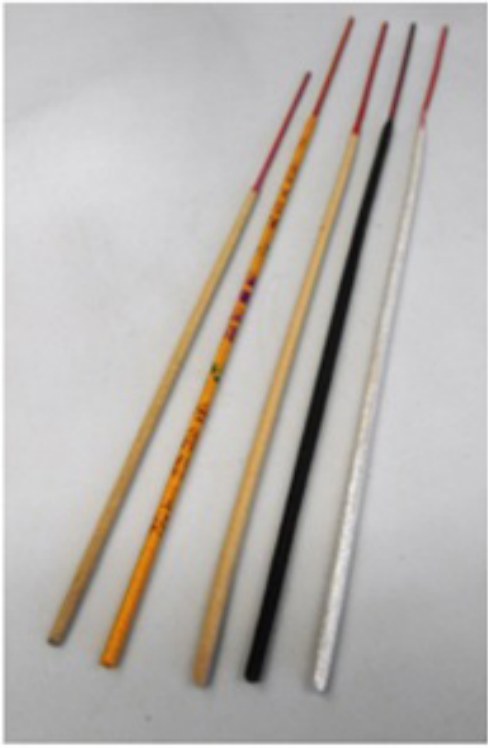

(3) Kode K-O

Catatan : Urutan kode A-O dari kiri ke kanan sesuai abjad

Gambar 3. Sampel Dupa 
Tabel 1. Pengamatan Fisik Sampel Dupa

\begin{tabular}{|c|c|c|c|c|c|c|c|c|}
\hline \multirow[b]{2}{*}{ Sumber } & \multirow[b]{2}{*}{ Kode } & \multirow[b]{2}{*}{ Warna/Keterangan } & \multicolumn{2}{|c|}{ Keseluruhan } & \multicolumn{2}{|c|}{ Bagian yang terbakar } & \multirow{2}{*}{$\begin{array}{c}\text { Waktu } \\
\text { pembakaran } \\
\text { (menit) }\end{array}$} & \multirow{2}{*}{$\begin{array}{c}\text { Laju } \\
\text { pembakaran } \\
\text { (mg/menit) }\end{array}$} \\
\hline & & & $\begin{array}{l}\text { Panjang } \\
(\mathrm{cm})\end{array}$ & $\begin{array}{c}\text { Berat } \\
\text { (g) }\end{array}$ & $\begin{array}{c}\text { Panjang } \\
(\mathrm{cm})\end{array}$ & $\begin{array}{c}\text { Diameter } \\
(\mathrm{mm})\end{array}$ & & \\
\hline \multirow{5}{*}{ Indonesia } & $\mathrm{A}$ & Merah, lebih mahal & $39,4 \pm 0,05^{a}$ & $1,61 \pm 0,12$ & $28,1 \pm 0,29$ & $6,1 \pm 0,4$ & $44,6 \pm 2,4^{b}$ & $25,5 \pm 1,2^{b}$ \\
\hline & B & Merah, ekonomis & $39,5 \pm 0,04$ & $1,87 \pm 0,12$ & $28,6 \pm 0,13$ & $6,4 \pm 0,8$ & $43,0 \pm 1,9$ & $31,1 \pm 1,8$ \\
\hline & C & Hitam, aroma & $32,2 \pm 0,07$ & $1,29 \pm 0,10$ & $23,0 \pm 0,32$ & $6,0 \pm 0,0$ & $51,2 \pm 5,4$ & $19,6 \pm 2,0$ \\
\hline & $\mathrm{D}$ & Merah, aroma & $39,0 \pm 0,00$ & $1,84 \pm 0,11$ & $28,2 \pm 0,13$ & $7,0 \pm 0,6$ & $50,4 \pm 3,1$ & $28,4 \pm 0,5$ \\
\hline & $\mathrm{E}$ & Merah tua, aroma & $38,1 \pm 0,10$ & $2,07 \pm 0,31$ & $28,2 \pm 0,17$ & $6,0 \pm 0,0$ & $59,7 \pm 2,9$ & $26,5 \pm 1,5$ \\
\hline \multirow{5}{*}{ Vietnam } & $\mathrm{F}$ & Coklat & $28,0 \pm 0,04$ & $2,77 \pm 0,14$ & $21,0 \pm 0,15$ & $14,0 \pm 0,0$ & $77,7 \pm 5,6$ & $29,6 \pm 1,5$ \\
\hline & G & Kuning & $43,0 \pm 0,17$ & $3,05 \pm 0,38$ & $28,7 \pm 0,35$ & $10,6 \pm 1,0$ & $66,5 \pm 5,7$ & $35,2 \pm 2,9$ \\
\hline & $\mathrm{H}$ & Coklat tua & $38,3 \pm 0,21$ & $2,08 \pm 0,06$ & $23,1 \pm 0,11$ & $7,9 \pm 0,1$ & $73,9 \pm 2,2$ & $23,4 \pm 0,4$ \\
\hline & I & Putih & $42,6 \pm 0,35$ & $3,51 \pm 0,58$ & $27,7 \pm 0,37$ & $13,3 \pm 1,4$ & $67,0 \pm 1,5$ & $34,2 \pm 2,5$ \\
\hline & $\mathrm{J}$ & Hitam & $28,9 \pm 0,08$ & $1,67 \pm 0,07$ & $22,1 \pm 0,14$ & $7,1 \pm 0,4$ & $61,4 \pm 1,4$ & $21,5 \pm 1,5$ \\
\hline \multirow{5}{*}{ Thailand } & $\mathrm{K}$ & Coklat, smokeless & $25.4 \pm 0.04$ & $0,, 72 \pm 0,03$ & $16,0 \pm 0,24$ & $4,0 \pm 0,0$ & $32,4 \pm 2,1$ & $17,0 \pm 1,7$ \\
\hline & $\mathrm{L}$ & Coklat, traditional & $32,0 \pm 0,11$ & $1,22 \pm 0,09$ & $21,7 \pm 0,34$ & $6,0 \pm 0,0$ & $29,3 \pm 1,3$ & $30,4 \pm 1,2$ \\
\hline & $M$ & Hitam, aroma & $32,1 \pm 0,07$ & $1,49 \pm 0,11$ & $22,0 \pm 0,14$ & $6,4 \pm 0,5$ & $32,9 \pm 0,8$ & $36,9 \pm 3,8$ \\
\hline & $\mathrm{N}$ & Warna-warni, aroma & $32,4 \pm 0,27$ & $1,37 \pm 0.09$ & $22,1 \pm 0,14$ & $6,4 \pm 0,5$ & $48,6 \pm 1,4$ & $23,8 \pm 2,3$ \\
\hline & 0 & Kuning, cap & $32,2 \pm 0,10$ & $1,16 \pm 0,03$ & $21,7 \pm 0,06$ & $6,0 \pm 0,0$ & $45,7 \pm 3,4$ & $18,7 \pm 1,1$ \\
\hline
\end{tabular}

a. nilai Mean $\pm \mathrm{SD}$, dari 7 eksperimen independen

b. nilai Mean $\pm \mathrm{SD}$, dari 3 eksperimen independen

Dari hasil pengamatan fisik terhadap masingmasing 5 jenis dupa berbeda dari tiap lokasi terlihat bahwa seluruh sampel dupa Indonesia terlihat memiliki aroma sejenis, dan tercium lebih kuat dibanding sampel-sampel lainnya. Panjang dupa bervariasi antara 32-39 cm dan ketebalan rata-rata bagian yang mudah terbakar adalah $6 \mathrm{~mm}$. Waktu pembakaran bervariasi antara 44-60 menit per batang. Dupa aroma berwarna hitam memiliki laju pembakaran terkecil yaitu $19,6 \pm 2,0 \mathrm{mg} /$ menit.

Seluruh sampel dupa Vietnam memiliki aroma tradisional dengan variasi panjang antara 28$43 \mathrm{~cm}$ dan diameter 7-14 mm. Selain itu waktu pembakaran berlangsung lebih dari 60 menit per batang, khususnya untuk dupa berwarna coklat kode F yaitu $77 \pm 5,6$ menit. Dupa berwarna kuning memiliki laju pembakaran tertinggi yaitu $35,2 \pm 2,9 \mathrm{mg} / \mathrm{menit}$. Sementara sampel dari Thailand memiliki banyak variasi seperti smokeless, tradisional, dan aromatik. Dupa-dupa tersebut umumnya lebih tipis $(\varnothing=4-6 \mathrm{~mm})$ dan lebih kecil $(25-32 \mathrm{~cm})$ dibanding lainnya, dengan variasi waktu pembakaran mulai 30-50 menit per batang. Dupa smokeless memiliki laju pembakaran paling rendah yaitu $17 \pm 1,7 \mathrm{mg} /$ menit.

Perbedaan berat dan ukuran dupa dari sampel-sampel tersebut terjadi akibat proses manufaktur yang umumnya dibuat secara manual. Proporsi dan ukuran bubuk dupa, serta panjang stik bambu atau kayu, dengan berat lebih besar dan bagian yang terbakar (combustible part) lebih panjang, seluruh sampel dupa Vietnam memiliki waktu pembakaran lebih lama dibanding lainnya. Kondisi pembakaran memegang peranan penting untuk menentukan tingkat emisi, durasi pembakaran menjadi menjadi salah satu parameter dalam menentukan jenis dupa yang baik (22). Dupa dengan laju pembakaran rendah diprediksi mengandung porsi material tak mudah terbakar yang lebih tinggi. Waktu pembakaran yang singkat kemungkinan dihasilkan dari pembakaran tak sempurna yang menghasilkan lebih banyak residu berupa abu (17). 


\section{Identifikasi PAHs}

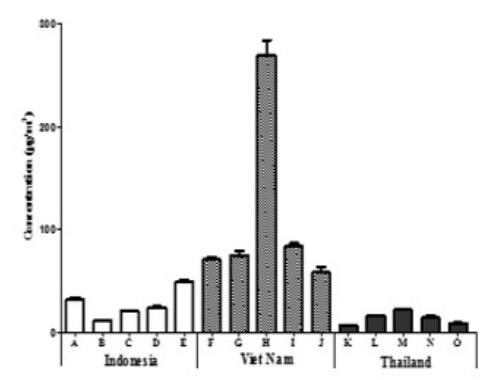

Total PAHs

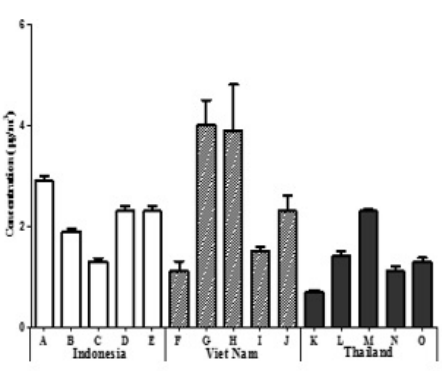

$\mathrm{BaP}$

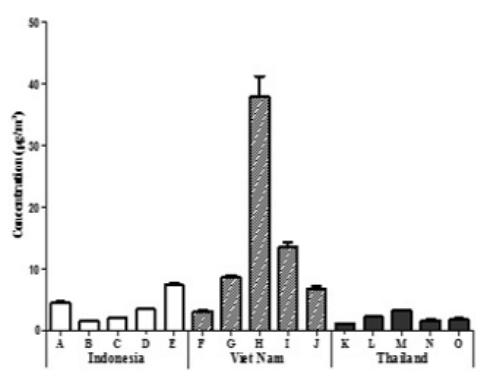

BaP equivalent

Gambar 4. Konsentrasi Total PAHs, BaP, dan BaP equivalent

Hasil analisis menunjukkan bahwa seluruh sampel dupa mengemisikan senyawa-senyawa PAHs dengan konsentrasi bervariasi, termasuk senyawa karsinogenik BaP. Perbedaan konsentrasi emisi PAHs dari berbagai sampel, turut dipengaruhi oleh jenis bahan baku dan ukuran dupa. Adanya penambahan berbagai senyawa sintetik berpotensi menambah sifat toksik. Paparan terkombinasi dari berbagai senyawa yang terkandung dalam dupa dapat menyebabkan efek aditif dan sinergis.

Terlihat bahwa sampel dupa dari Vietnam ternyata mengemisikan PAHs paling tinggi dibanding sampel lainnya. Salah satu sampel dupa Vietnam (kode H) bahkan mengemisikan total PAHs dengan konsentrasi jauh lebih tinggi $\left(270 \mathrm{\mu g} / \mathrm{m}^{3}\right)$ dari sampel lainnya. Konsentrasi total PAHs bervariasi antara 6,35$287,6 \mathrm{\mu g} / \mathrm{m}^{3}$. Konsentrasi BaP dalam asap dupa terukur antara $0,67-5,01 \mathrm{\mu g} / \mathrm{m}^{3}$, yang paling tinggi terdapat dalam sampel kode $\mathrm{G}$. Nilai BaP equivalent terhitung bervariasi dari 1,12 sampai 43,07 $\mathrm{\mu g} / \mathrm{m}^{3}$.

Sampel dupa Vietnam mengemisikan total PAHs $\sim 5$ kali lebih tinggi dari dupa Indonesia dan $\sim 8$ kali lebih tinggi dari dupa Thailand. Umumnya seluruh sampel mengemisikan $\mathrm{BaP}$ dalam konsentrasi yang setara, meskipun nilai $\mathrm{BaP}$ dupa Vietnam tetap $\sim 1,3$ dan $\sim 1,8$ kali lebih besar dibanding dupa Indonesia dan Thailand. Senyawa PAHs dominan yang ditemukan dalam sampel dupa Indonesia dan

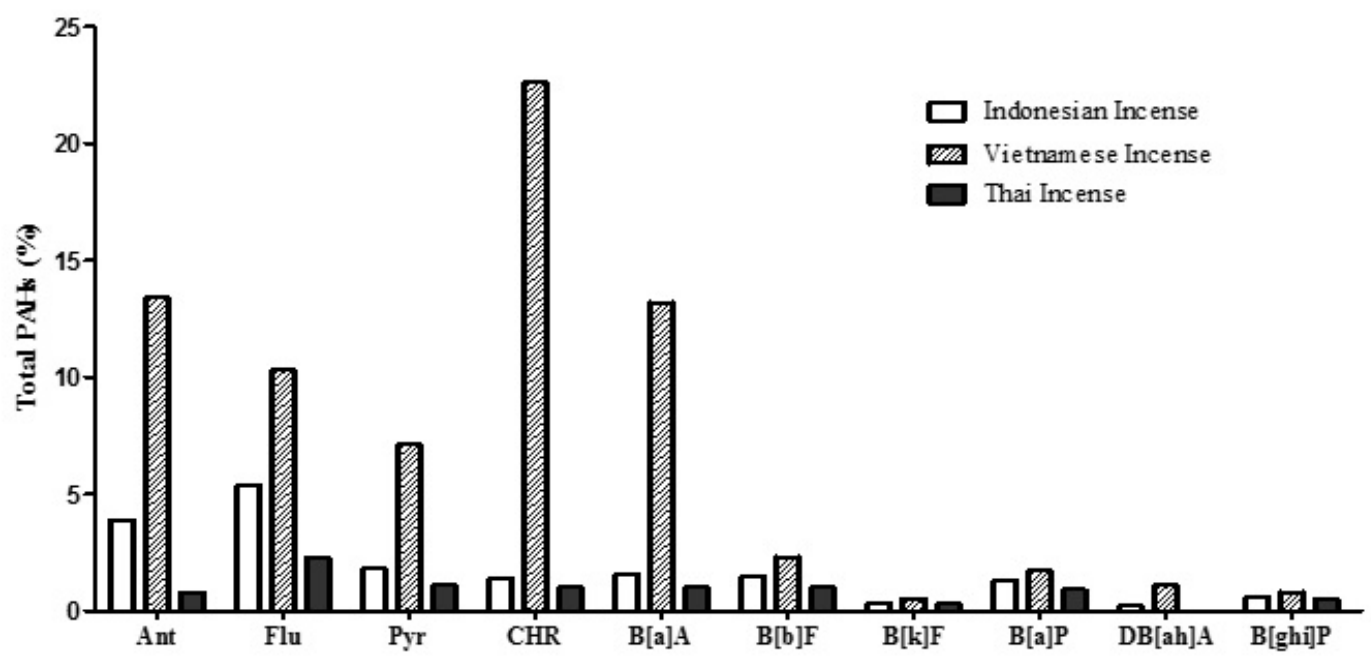

Gambar 5. Distribusi PAHs dalam berbagai sampel dupa 
Thailand adalah Flu sebesar $8,2 \pm 1,0 \mu \mathrm{g} / \mathrm{m}^{3}$ dan $3,5 \pm 0,5 \mu \mathrm{g} / \mathrm{m}^{3}$, sedangkan dalam sampel dupa Vietnam adalah CHR $(34,5 \pm 10,6 \mu \mathrm{g} /$ $\mathrm{m}^{3}$ ). Distribusi kandungan PAHs dalam tiap sampel dapat dilihat pada gambar 4. Dari gambar tersebut terlihat masing-masing komponen profil PAHs yang mendominasi dari tiap sampel dupa. Sampel dupa Vietnam mendominasi pola PAHs, dengan prosentase CHR (22,6\%) dari total PAHs, diikuti oleh Ant $(13,4 \%)$ dan B[a]A (13,2\%).

Perbedaan pola PAHs ditemukan dalam tiap jenis sampel dupa yang berbeda. Panjang dan proporsi batang bambu, bahan baku dan ukuran bubuk dupa, serta kandungan zat aditif akan berpengaruh pada emisi PAHs. Lung et al., (2003) menemukan komposisi AcP $>$ Phe $>$ Ant $>$ Flu $>$ Pyr (17) dan Yang et al., (2007) melaporkan $\mathrm{CHR}>\mathrm{BaP}>\mathrm{BaA}$ (23) dalam pengamatan mereka. Hasil studi menunjukkan Flu>Ant $>$ Pyr merupakan senyawa PAHs dominan dalam sampel Indonesia, $\mathrm{CHR}>\mathrm{Ant}>\mathrm{BaA}$ dalam sampel Vietnam dan Flu $>$ Pyr $>$ CHR dalam sampel Thailand. Walaupun tidak identik, namun komponen senyawa PAHs dengan BM rendah ditemukan diantara sampel-sampel tersebut. WHO menyatakan tidak ada ambang batas yang dapat ditentukan untuk senyawa PAHs dan paparan di dalam ruangan dianggap signifikan bagi kesehatan manusia (24).

\section{SIMPULAN}

Pembakaran dupa mengemisikan berbagai senyawa kompleks berbahaya yang bersifat racun seperti PAHs. Konsentrasi senyawa PAHs dari hasil pembakaran di ruang eksperimen terukur dalam kondisi tanpa gangguan dari lingkungan sekitar. Sampel dupa Vietnam mengemisikan senyawa PAHs dengan konsentrasi lebih tinggi dibanding dupa dari Indonesia dan Thailand Kesamaan pola emisi PAHs dari pembakaran semua sampel dupa adalah ditemukannya tigadan empat-cincin komponen PAHs yang mendominasi total PAHs.

Dari hasil kegiatan ini diketahui bahwa asap dupa mengemisikan berbagai senyawa berbahaya, namun dalam kenyataannya para pengguna tidak menyadari hal tersebut. Dengan demikian, informasi mengenai dampak pembakaran dupa terhadap kesehatan akan sangat penting bagi masyarakat. Kesadaran publik mengenai produksi dan penggunaan harmless incense dan kampanye untuk tidak membakar dupa dalam ruangan berventilasi buruk sebaiknya diperkenalkan kepada masyarakat.

\section{UCAPAN TERIMA KASIH}

Penulis mengucapkan terimakasih pada Thailand International Cooperation Agency (TICA) dan ASEAN Foundation yang telah membantu pendanaan, serta kepada CRI yang telah menyediakan sarana, fasilitas dan peralatan dalam pengujian.

\section{DAFTAR PUSTAKA}

(1) Nazaroff WW. Indoor particle dynamics. Indoor air. 2004;14 Suppl 7:175-83.

(2) Long CM, Suh HH, Koutrakis P. Characterization of Indoor Particle Sources Using Continuous Mass and Size Monitors. J Air Waste Man Assoc. 2000;50(7):1236-50. 
(3) Navasumrit P, Arayasiri M, Hiang OMT, Leechawengwongs M, Promvijit J, Choonvisase S, et al. Potential health effects of exposure to carcinogenic compounds in incense smoke in temple workers. Chem Biol Interact. 2008;173(1):19-31.

(4) Chiang KC, Liao CM. Heavy Incense Burning in Temples Promotes Exposure Risk from Airborne PMs and Carcinogenic PAHs. The Science of the total environment. 2006;372(1):64-75.

(5) Chiang K-C, Chio C-P, Chiang Y-H, Liao C-M. Assessing hazardous risks of human exposure to temple airborne polycyclic aromatic hydrocarbons. J Hazard Mater. 2009;166(2):676-85.

(6) Yang $\mathrm{T}$, Lin $\mathrm{T}, \mathrm{Wu} \mathrm{J}$, Jhuang $\mathrm{F}$. Characteristics of Polycyclic Aromatic Hydrocarbon Emissions of Particles of Various Sizes from Smoldering Incense. Bulletin of Environmental Contamination and Toxicology. 2012;88(2):271-6.

(7) Friborg JT, Yuan J-M, Wang R, Koh W-P, Lee H-P, Yu MC. Incense use and respiratory tract carcinomas: a prospective cohort study. Cancer 2008;113(7).

(8) Tse L, Yu I, Qiu H, Au JS, Wang XR. A Case-referent Study of Lung Cancer and Incense Smoke, Smoking, and Residential Radon in Chinese Men. Environ Health Persp. 2011;119(11):1641-6.

(9) Lin TS, Shen FM. Trace Metals in Chinese Joss Stick Smoke. Bulletin of Environmental Contamination and Toxicology. 2003;71(1):135-41.
(10) Lee R, Lin J. Gaseous aliphatic aldehydes in smoke from burning raw materials of Chinese joss sticks. Bulletin of Environmental Contamination and Toxicology. 1996;57(3):361-6.

(11) Wang B, Lee S, Ho K. Chemical composition of fine particles from incense burning in a large environmental chamber. Atmos Environ. 2006;40(40):7858-68.

(12) Qureshi S. Preliminary studies on general and genetic toxicity of incense (Bakhour) inhalation in Swiss albino mice. World J Med Sci. 2013;8(2):7984.

(13) Yang T, Lin T-S, Chang M. Characteristics of Emissions of Volatile Organic Compounds from Smoldering Incense. Bull Environ Contam Toxicol. 2007;78(5):308-13.

(14) Lin J, Tang C. Characterization and aliphatic aldehyde content of particulates in Chinese incense smoke. Bulletin of Environmental Contamination and Toxicology. 1994;53(6):895-901.

(15) Lin TC, Chang FH, Hsieh JH, Chao HR, Chao MR. Characteristics of polycyclic aromatic hydrocarbons and total suspended particulate in indoor and outdoor atmosphere of a Taiwanese temple. Journal of hazardous materials. 2002;95(1-2):112.

(16) Lin JM, Lee JK. Vaporous and particulate bound polycyclic aromatic hydrocarbons in Chinese incense smoke. Toxicol Environ Chem. 1998;67(1-2):105-13. 
(17) Lung SC, Hu SC. Generation rates and emission factors of particulate matter and particle-bound polycyclic aromatic hydrocarbons of incense sticks. Chemosphere. 2003;50(5):6739.

(18) Lin TC, Yang CR, Chang FH. Burning characteristics and emission products related to metallic content in incense. Journal of hazardous materials. 2006;140(1-2):165-72.

(19) Lin TC, Krishnaswamy G, Chi DS. Incense Smoke: Clinical, Structural and Molecular Effects on Airway. Clin Mol Allergy. 2008;6:3.

(20) USEPA. Polycyclic Aromatic Hydrocarbons (PAHs)2008.
(21) ATSDR. Toxicological profile for Polycyclic aromatic hydrocarbons (PAHs). In: Registry USDoHHSAfTSaD, editor. Atlanta: U.S. Governement Printing Office; 1995.

(22) Lin T-C, Yang C-R, Chang F-H. Burning characteristics and emission products related to metallic content in incense. Journal of hazardous materials. 2007;140(1):165-72.

(23) Yang CR, Lin TC, Chang FH. Particle Size Distribution and PAH Concentrations of Incense Smoke in a Combustion Chamber. Environ Poll. 2007;145(2):606-15.

(24) WHO. WHO Guidelines for Indoor Air Quality: Selected Pollutants. Copenhagen: WHO Regional Office for Europe; 2010. 